\title{
OBITUARY
}

\section{CECIL GORDON ROBERTS}

Cecil Gordon Roberts, formerly Deputy Treasury Medical Adviser, died suddenly on September 8, 1954, at the age of 48, at Tamworth, Australia, while spending a short holiday with his wife.

Dr. Roberts spent his early childhood near Liverpool ; he was educated at Uppingham College, at Cambridge, and at the Westminster Hospital, London. At Cambridge he took a Natural Science Tripos, Part II, in physiology and for the rest of his life he remained interested in physiological problems. He became a resident medical officer at the Westminster Hospital and, later, resident physician at Ruthin Castle. He was offered a registrar's job at Westminster Hospital, but after getting married he joined the Medical Branch of the General Post Office in 1934, under Sir Henry Bashford, who was then Chief Medical Officer, and served there from then onwards until 1953. He was promoted Second Medical Officer in 1943 and Chief Medical Officer in 1945. When the Treasury Medical Adviser's office and the Medical Branch of the General Post Office were merged into the Treasury Medical Service in 1948, he became Deputy Treasury Medical Adviser, retaining charge of the medical affairs of the Post Office. In 1953, he was attracted by the possibility of organizing and building up an important medical service in Australia, and he applied for the post of Director of the Division of Industrial Hygiene, New South Wales Department of Public Health, Sydney, Australia. With such wide experience and personal qualities, his friends were not surprised that he was selected for the post.
Through his family he was connected with merchant adventure, as his father traded with South America; one of his ancestors was founder of Emmanuel College, Cambridge, and one of his less distant relatives was a high civil servant in the Treasury in the nineteenth century. Of all those connexions, rooted so deeply in British tradition, Dr. Roberts was very conscious and proud.

He was very keen on history and the study of evolution, both in the field of natural and social conditions. He was a cheerful man, full of optimism and vitality, much interested in every new aspect of his own subject as well as in the general progress of mankind. During the war years that high spiritedness combined with his energy, drive, and hard work, contributed to a great extent to carrying out the difficult task of the service he was working for. He enjoyed travel, good food, and good company, and he was a most charming conversationalist. He was a born speaker but behind the ease and elegance of his oratory there was a sincerity and seriousness of purpose in trying to improve social conditions in general and especially the fortunes of the people under his care. The freshness of his approach and his underlying scientific attitude became an important support in the development of industrial medicine in this country in the last decade.

His death means a great loss, not only to his friends and collaborators, but also to his branch of medicine, and to the former Post Office Medical Service in particular. He leaves a widow and two sons.

W. E. Chiesman 